\title{
Topographic and geometric controls on glacier changes in the central Tien Shan, China, since the Little Ice Age
}

\author{
Yanan LI, Yingkui LI \\ Department of Geography, University of Tennessee, Knoxville, TN, USA \\ E-mail: yli32@utk.edu
}

\begin{abstract}
This paper examines the topographic and geometric controls on glacier changes in area and equilibrium-line altitude (ELA) in the central Tien Shan, China, since the Little Ice Age (LIA). We delineate the extents of $\mathbf{4 8 7}$ modern glaciers and their corresponding maximum LIA glacial advances using satellite imagery in Google Earth, and analyze the relationships between the magnitude of glacier changes and a set of local topographic/geometric factors including glacier area, slope, aspect, shape, hypsometry and mean elevation. Our results show that: (1) glacier area decreased from $460.2 \mathbf{~ k m}^{2}$ during the LIA to $265.6 \mathrm{~km}^{2}$ in the 2000s (a loss of $42.3 \%$ ), with an average ELA increase of $\sim 100 \mathrm{~m}$; (2) relative area changes of glaciers are strongly affected by two of these local factors (glacier area and mean elevation); and (3) ELA change does not show a strong relationship with local factors, suggesting that it may be controlled mainly by climatic factors. This study provides important insights into the local controls on glacier changes at the centennial timescale, which are of critical importance to assess future glacier changes in this arid and semi-arid region.
\end{abstract}

KEYWORDS: climate change, geomorphology, glacial geomorphology, glacier mapping, remote sensing

\section{INTRODUCTION}

Meltwater from glaciers plays an important role in sustaining human habitats and ecosystems, especially for arid and semiarid regions like central Asia. Glacial retreat in central Asia alters moisture-bearing atmospheric circulations, induces glacier lake and streamflow outburst flooding, and may ultimately cause desertification, recolonization of plants and animals, and human migration (Chen and others, 2005; Wang, 2010; Gao and others, 2013). Known as the 'water tower of central Asia', the Tien Shan, China, possess a high concentration of mountain glaciers (Liu and Han, 1992; Solomina and others, 2004; Aizen and others, 2007; Sorg and others, 2012). Variations in glacial meltwater may lead to political disputes since multiple countries in central Asia with millions of people share the same rare water sources from these glaciers.

Like many other regions of the world, the Tien Shan has been experiencing glacial retreat since the end of the Little Ice Age (LIA) in the mid-19th century, with an accelerated rate in recent decades (Khromova and others, 2003; Narama and others, 2010; Bolch and others, 2012; Sorg and others, 2012). The surface mass balance of glaciers in the Tien Shan is controlled by the interaction of the westerlies and the Siberian high. Westerlies bring moist air masses during summer months, and precipitation from June to August accounts for $32-50 \%$ of annual precipitation in different altitudinal zones of the central Tien Shan (Aizen and others, 1995). In winter (November-February), the Siberian high invades this area, bringing cold and dry air masses, and only $8-10 \%$ of the annual precipitation occurs (Aizen and others, 1995). In addition, glacier changes are affected by local topographic/geometric characteristics. For example, studies of mountain glaciers in northwestern China and the Himalaya suggest that small glaciers have changed more significantly than large ones in recent decades (Liu and others, 2003; Bhambri and others, 2011; Li and others, 2011). Statistical analysis of glaciers from the World Glacier Inventory (http://nsidc.org/data/glacier_inventory/) reveals that most glaciers in mid-high latitudes have poleward aspects due to limited solar radiation (Evans, 2006). A recent study found that the contribution of glacial melting to sea-level rise on a global scale determined by measurements of monitored glaciers might be overestimated because these monitored glaciers, which are relatively easy to access, are also more vulnerable to climate change, whereas relatively stable glaciers distributed in rough terrain are usually hard to reach (Kerr, 2013). However, only limited studies have been conducted to examine systematically the relationship between local topographic/geometric factors and glacier changes.

Most glacial studies in the Tien Shan have been focused on either the most recent decades or paleoglaciations before the Holocene, whereas few studies have been conducted on the centennial timescale. In particular, little is known about glacial fluctuations since the LIA. The LIA was a cold period during the last millennium, between approximately AD 1550 and AD 1850 (Grove, 2004). Geomorphic evidence of several glacial advances in recent centuries confirmed its occurrence, and the LIA moraines in the Tien Shan are empirically identified as fresh, bouldery and sharp-crested moraines within hundreds of meters to a few kilometers of the modern glacier terminus (Shi and Ren, 1990; Solomina, 2000). The timing of the LIA glacial advances in the Tien Shan has been constrained using lichenometry and radiocarbon dating, ranging from $412 \pm 20$ to $79 \pm 20 \mathrm{BP}$ (Chen, 1989; Yi and others, 2004, 2008).

In the work presented here, we delineate 487 modern glaciers and their corresponding LIA extents from the satellite imagery in Google Earth to evaluate the topographic/geometric controls on glacier changes in the central Tien Shan. We derive glacier area directly from the delineated glacier polygon. We also calculate five other local factors, including slope, aspect, shape, hypsometry and mean elevation, using the Advanced Spaceborne Thermal Emission and Reflection Radiometer (ASTER) global 

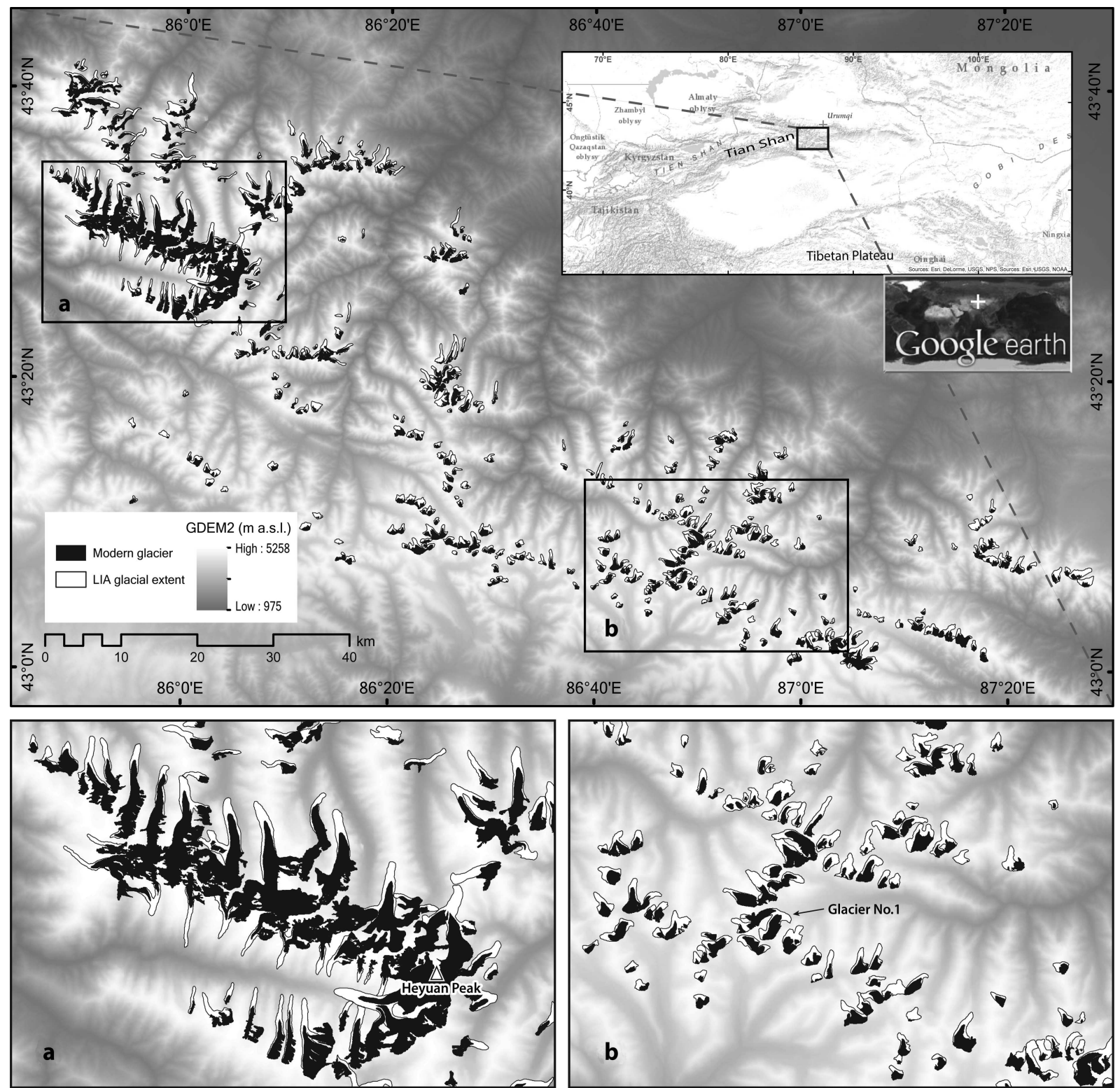

Fig. 1. Map of the study area overlapped with GDEM2. 487 modern glaciers (only those with corresponding LIA extents) are illustrated as black polygons and LIA extents are shown as black outlines. Inset shows the terrain in central Asia, the extent of the Tien Shan, and the city of Ürümqi (cross) close to our study area (box). The Google Earth inset shows the location of our study area in the world. Two enlarged areas give detailed delineations of modern glaciers and LIA glacial extents around (a) Heyuan peak and (b) Ürümqi river headwaters.

digital elevation model version 2 (GDEM2, $30 \mathrm{~m}$ resolution). Statistical analysis is used to examine the relationship between the magnitude of glacial retreat and these local factors. We assume that glaciers were affected by similar changes in climate conditions from the LIA to the present within this confined area. This study provides the first regional view of glacial retreat since the LIA in the central Tien Shan.

\section{STUDY AREA}

The Tien Shan is a series of mountain ranges with a westsouthwest-east-northeast trend, $\sim 2500 \mathrm{~km}$ long and extending from the western boundary of Kyrgyzstan across the Xinjiang Uighur Autonomous Region in China and almost reaching Mongolia (Fig. 1). Most of these mountain ranges reach $\sim 4000 \mathrm{~m}$ a.s.l., with the highest peaks $>7000 \mathrm{~m}$ a.s.l. along the boundary between China and Kyrgyzstan (Xu and others, 2010). It is one of the driest regions in the world, located in the center of the Eurasian continent. The barrier effects of the terrain lead to a decreasing gradient in precipitation from northwest (annual precipitation 1500-2000 mm) to southeast $(\sim 100 \mathrm{~mm})$ (Grove, 2004; Sorg and others, 2012). Our study area is located in the central sector of the Tien Shan, belonging to the eastern part of the Eren Habirga range $\left(43^{\circ} 38^{\prime}-42^{\circ} 55^{\prime} \mathrm{N}, 85^{\circ} 40^{\prime}-87^{\circ} 22^{\prime} \mathrm{E}\right)$. Large valley glaciers are distributed around the highest peak of Heyuan mountain (5289 ma.s.l.), whereas cirque glaciers, hanging glaciers and small valley glaciers are dispersed across the rest of the study area (Fig. 1). Abundant U-shaped valleys and other glacial landforms indicate that this area was extensively glaciated in the past. One well-studied site in this region is the Ürümqi river headwaters where the Chinese Academy of Sciences established a glaciological station in 1959 to monitor the dynamics of glaciers. The station includes a meteorological observation field, a 


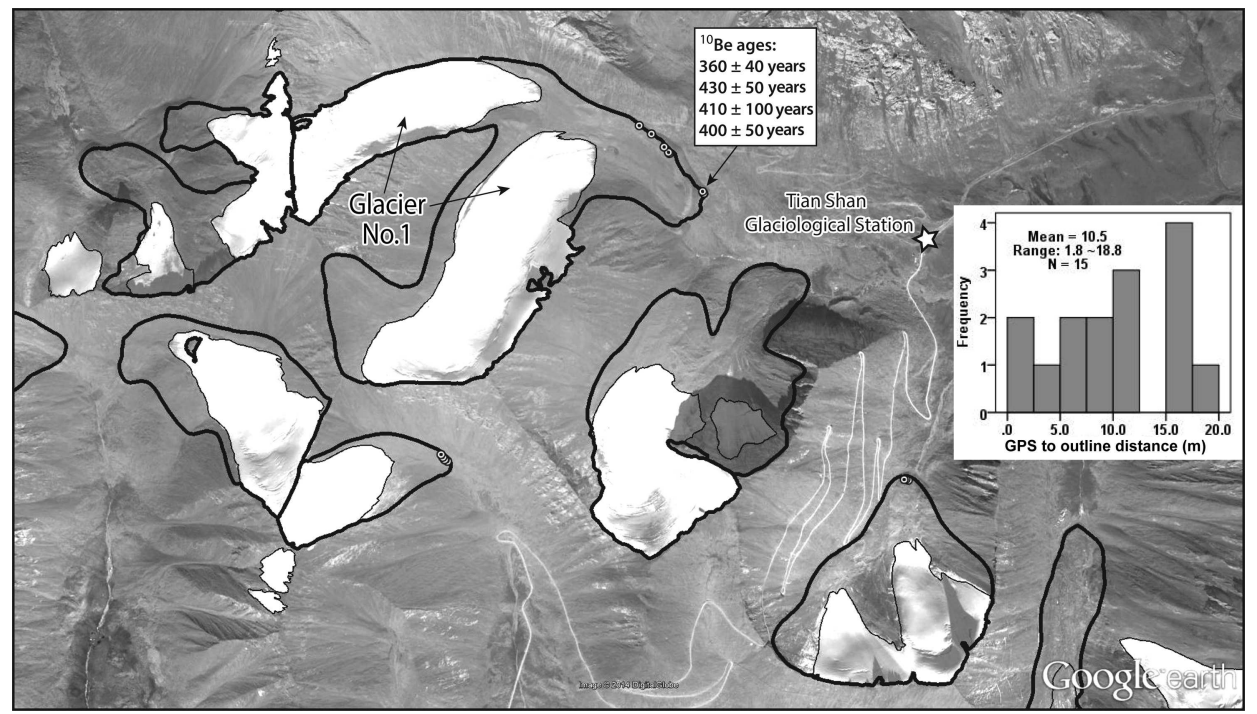

Fig. 2. A bird's-eye view of the Ürümqi river headwaters in Google Earth, with delineated modern (thin line) and LIA (thick line) glacier outlines, 15 field-measured GPS coordinates (dots), and four ${ }^{10}$ Be dating results marked in the box. The frequency distribution of the shortest distances from 15 GPS coordinates to their corresponding LIA outlines is illustrated in the bar chart. Tien Shan glaciological station is indicated by the star.

hydrological station and a cold-area plant-testing field. Since 1959, it has conducted long-term continuous monitoring of glacier physics, chemistry and energetic characteristics (mainly for Ürümqi glacier No. 1), as well as various studies associated with glacial geomorphology, hydrology and ecology (e.g., Li and others, 2001, 2011; Ye and others, 2005; Gao and others, 2013). Meltwater from the glaciers around this station provides fresh water for over 3 million people in the city of Ürümqi.

\section{DATA AND METHODS}

\section{Satellite imagery and glacier outline delineation}

Google Earth has become one of the most popular virtual globes, with free access to high-resolution imagery covering the whole world (Yu and Gong, 2012). It integrates satellite imagery, aerial photographs and digital maps into a threedimensional interactive platform (Sun and others, 2012). The resolution of Google Earth imagery (DigitalGlobe) in some regions can reach $0.6 \mathrm{~m}$ (Frankl and others, 2013). In remote areas, such high-resolution imagery and handy interactive visualization operations provide a unique opportunity to map glacier changes with relatively high accuracy. We used Google Earth to identify and delineate the extents of modern glaciers and their corresponding LIA moraines. In our study area, the date of the imagery spans 2002-12, but most is from 2010 (see supplementary material at http://www. igsoc.org/hyperlink/66a031/). The outlines of modern and LIA glaciers were delineated as polygon features. The LIA glacial advances in the Tien Shan were usually represented by two or three lateral-terminal moraines (Shi and Ren, 1990; Liu and others, 2003). We regarded the outermost moraine as the maximum extent of the LIA glacial advances. Debris cover was not a major issue in delineating glacier boundaries because most glacier surfaces in this area are clean. We excluded a few glaciers that were partially covered by clouds. In total, we manually delineated 487 modern glaciers and their corresponding LIA maximum extents in Google Earth.
Field measurements and validation of the delineation

Fieldwork was conducted in the Ürümqi river headwaters in 2010 and 2012. In 2010, we collected four boulder samples on top of the outermost LIA moraine of Ürümqi glacier No.1 and obtained tightly clustered ${ }^{10} \mathrm{Be}$ ages from $360 \pm 40$ to $430 \pm 50$ years with a weighted mean of $400 \pm 70$ years ( $\mathrm{Li}$ and others, unpublished data; Fig. 2). These ages are consistent with that of $412 \pm 20$ years BP dated using lichenometry (Chen, 1989) and those of $416 \pm 146$ and $428 \pm 127$ calibrated years BP based on accelerator mass spectrometry ${ }^{14} \mathrm{C}$ dating of inorganic carbonate coating from the same moraine ( $\mathrm{Yi}$ and others, 2004; Li and others, 2011). These ages indicate that the fresh moraines close to modern glaciers were formed during the LIA in this area. In 2012, we recorded additional GPS coordinates from the top of LIA moraines in this area to evaluate the accuracy of the delineation from Google Earth. A total of 15 GPS coordinates on the ridge of the outermost LIA moraines in front of three individual glaciers were used as 'ground truth' to assess the accuracy of our delineation by examining the proximity between the delineated outlines and GPS measurements (Li and others, 2008; Fig. 2).

\section{Indicators of glacier changes since the LIA}

A variety of indicators has been used to quantify glacial advance/retreat, including changes in glacier area (Narama and others, 2010; Kamp and others, 2011), glacier length (Cook and others, 2005; Huybers and Roe, 2009), equilibrium-line altitude (ELA) (Benn and Lehmkuhl, 2000; Asahi, 2010) and glacier volume (Liu and others, 2003; Bliss and others, 2013). Area change is a commonly used indicator because it can be derived relatively easily from glacial extents in different time slices. Relative area change has been used to compare the relative magnitude of glacier change among different regions, but it does not account for the changes in ice thickness, so it may not reflect the actual total mass loss. ELA is an indicator of glacier mass balance, and $\triangle E L A$ has been widely used in paleoclimate research to reconstruct past temperature and/or precipitation (e.g. Yang 
and others, 2008; Asahi, 2010). We selected the relative area change and $\triangle E L A$ as two major indicators to quantify the glacier changes since the LIA.

\section{Relative area change}

Glacier area $\left(\mathrm{m}^{2}\right)$ can be derived directly from the delineated glacier outline (polygon). The relative change of glacier area $(\%)$ can be determined using

$$
\Delta A=\left(1-\frac{\Sigma A_{\mathrm{M}}}{A_{\mathrm{LIA}}}\right) \times 100
$$

where $\Delta A$ is the percentage of glacier area change, $A_{M}$ is the area of the modern glacier and $A_{\mathrm{LIA}}$ is the glacier area during the LIA. If several glaciers coalesced during the LIA, we assigned the same percentage to all modern glaciers using the total area of individual glaciers and their corresponding LIA extent.

\section{ELA estimation}

Benn and Lehmkuhl (2000) introduced six major methods that have been commonly used to estimate ELAs in past glaciations: the balance ratio (BR), the accumulation-area ratio (AAR), the maximum elevation of lateral moraines (MELM), the toe-headwall altitude ratio (THAR), the toesummit altitude method (TSAM) and the cirque-floor altitude. We used the TSAM in our study. The TSAM determines the ELA by calculating the mean elevation between the highest peak within the glacier catchment and the terminus of each glacier at a certain period (Benn and Lehmkuhl, 2000). Although this method is usually considered inaccurate (Torsnes and others, 1993), Maisch (1992) compared the directly measured $\triangle E L A$ since AD 1850 with the front elevation change calculated from 684 glaciers in the European Alps and concluded that half of the front elevation change, the same value derived using the TSAM if assuming a constant summit elevation, is about the same as the measured $\triangle E L A$. The TSAM has also been applied to estimate $\triangle E L A s$ for $>1000$ glaciers in the Tibetan Plateau and Mongolia (Benn and Lehmkuhl, 2000). We used the elevations derived from GDEM2 to determine the ELA change since the LIA maximum for each glacier.

\section{Local topographic/geometric factors}

We derived the following topographic/geometric parameters in GIS:

1. Glacier area, as mentioned above, was derived directly from the delineated glacier outline.

2. Slope (in ${ }^{\circ}$ between $0^{\circ}$ and $90^{\circ}$ ) was determined as the mean slope of each raster cell within the glacier outline.

3. Aspect is the direction of the steepest slope, in ${ }^{\circ}$ counted from north $\left(0^{\circ}\right)$ and increasing clockwise. We determined the average aspect for each glacier by calculating the directional mean of the aspect from each raster cell within the glacier outline.

4. Shape index $(\mathrm{SI})$ was derived from $\mathrm{SI}=\sqrt{\left(4 \pi \times A / P^{2}\right)}$, where $A$ is the area and $P$ is the perimeter of the glacier outline. SI ranges from 0 to 1 , with a value of 1 for a circular polygon.

5. Mean elevation represents the absolute altitudinal location of a glacier on the mountain. It was derived by averaging the elevations of all DEM cells within the glacier outline.
6. Hypsometric integral (HI), also called the 'elevationrelief ratio', was calculated using the difference between the mean and minimum elevations divided by the local relief (maximum elevation - minimum elevation) within the glacier outline (Pike and Wilson, 1971). HI ranges from 0 to 1 ; smaller values indicate a concave hypsometric curve (more ice distributed at low elevations), and the converse.

\section{Statistical analysis}

We first explored the descriptive statistics of each factor to examine the overall characteristics of the 487 glaciers, including the mean, median, standard deviation, minimum and maximum values. We then applied multivariate regressions to quantify the relationships between glacier changes (both relative area change and $\triangle E L A$ ) and these local topographic/geometric factors. We treated relative glacier area change and $\triangle E L A$ as dependent variables for each regression, and six factors (glacier area, slope, aspect, shape, hypsometry and mean elevation) as independent variables. Glacier area was transformed into its logarithmic value in the regression because of the apparent diminishing trend in its frequency distribution (Fig. 3a). The $R^{2}$ value was used to evaluate the goodness of fit, and the $p$ value to determine the significance level of the statistics. We also used scatter plots to visually examine the relationships between glacier changes and the statistically significant factors.

\section{RESULTS AND DISCUSSION \\ Accuracy of delineated glacier outlines in Google Earth}

We used 15 field-measured GPS coordinates from the top of the outermost LIA moraines in the Ürümqi river headwaters to assess the accuracy of the delineation. The offsets between these GPS coordinates and their corresponding delineations range from 1.8 to $18.8 \mathrm{~m}$, with an average of $10.5 \mathrm{~m}$. The minimum offset occurs at a lateral moraine, whereas the maximum is at a terminal moraine (Fig. 2). This difference is probably caused by the fact that the ridges of lateral moraines in this area are relatively sharp and narrow, whereas the ridges of terminal moraines are relatively flat and wide. Nonetheless, all the offsets are within one pixel of the Landsat imagery commonly used to delineate glacier outlines (Paul and others, 2004; Bolch, 2007; Bhambri and others, 2011). Therefore, the delineated glacier outlines in Google Earth are relatively accurate compared with most glacier maps derived from Landsat imagery.

\section{Glacier characteristics and glacier changes since the LIA}

The total area of the 487 glaciers we delineated in the central Tien Shan is $265.6 \mathrm{~km}^{2}$ in the $2000 \mathrm{~s}$. Most glaciers are $<1.0 \mathrm{~km}^{2}$ (430 of $487,88.3 \%$ ) (Fig. 3a), and the glacier with the largest area $\left(8.8 \mathrm{~km}^{2}\right)$ is located near the Heyuan peak. The average slopes of these 487 glaciers have a mean value of $33.6^{\circ}$ (Fig. 3b). The mean value is $\sim 10^{\circ}$ greater than the mean slope of the 488 glaciers in the eastern Himalaya (Racoviteanu and others, 2008), but similar to the mean slope $\left(29.4^{\circ}\right)$ in the Bogeda range, eastern Tien Shan ( $\mathrm{Li}$ and others, 2011). We divided the aspect of glaciers into eight $45^{\circ}$ intervals. $90.3 \%$ of glaciers are north-facing (north, northwest and northeast) (Fig. 3c). However, during the delineation, we observed some LIA moraines on the 

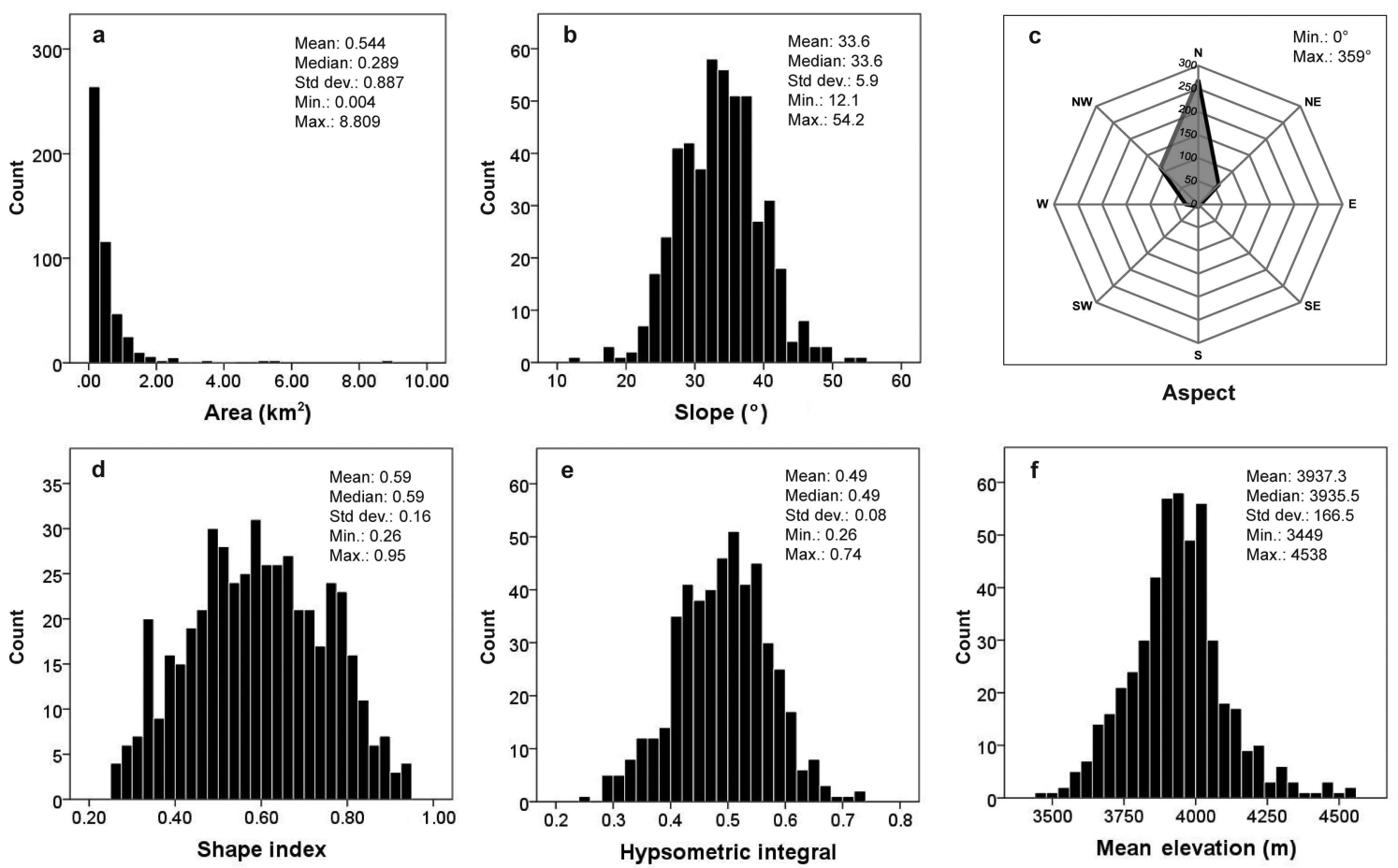

Fig. 3. Frequency distribution of six local topographic/geometric parameters: (a) area, (b) slope, (c) aspect, (d) shape index, (e) hypsometric integral and (f) mean elevation.

southern slopes without corresponding modern glaciers, indicating the existence of south-facing glaciers that disappeared after the LIA. The SI values of these glaciers range from 0.26 to 0.95 , with the mean and median at $\sim 0.60$ (Fig. 3d). Elongated glaciers concentrate around the Heyuan peak, but most glaciers do not extend far into the valley. Small hanging and mountain-top glaciers tend to be round in shape. The hypsometric integral values show a normal distribution with a mean of 0.49 (Fig. 3e). The mean elevations of most glaciers are between 3800 and $4100 \mathrm{~m}$ a.s.l., with an average of $3937 \mathrm{~m}$ a.s.l. (Fig. 3f). The present ELAs we derived using the TSAM are similar to these mean elevations.

The total glacial coverage we delineated during the LIA maximum is $\sim 460.2 \mathrm{~km}^{2}$, indicating an area reduction of $\sim 42.3 \%$ during this 300-400 year period. Relative area reduction for individual glaciers has a wide range of $8.4-98.2 \%$, and 261 of the 487 glaciers have $>50 \%$ area loss (Fig. $4 \mathrm{a}$ ). The $\triangle$ ELAs of these glaciers show a positively skewed distribution, with a mean of $101 \mathrm{~m}$ and a median of
$81 \mathrm{~m}$ (Fig. 4b). Our derived mean $\triangle \mathrm{ELA}$ since the LIA in the central Tien Shan is within the $\triangle E L A$ range of $100-150 \mathrm{~m}$ in the same period estimated by Porter (1970) using the AAR method for the temperate zone of the Northern Hemisphere. $\triangle E L A$ in the Kyrgyz Tien Shan since the LIA, estimated using the TSAM, is $\sim 75-100 \mathrm{~m}$ (Solomina and others, 2004).

\section{Relationships between glacier changes and local topographic/geometric factors}

\section{Relationship between $\triangle E L A$ and local factors}

The $R^{2}$ value in the regression between $\triangle \mathrm{ELA}$ and six local factors is 0.162 (Table 1). Despite this, the $t$ tests for aspect, slope, shape and the whole regression all passed the significance level of $0.001(p<0.001$; Table 1$)$. This low $R^{2}$ value means that only $16.2 \%$ of the variation in $\triangle E L A$ is explained by these local factors, indicating that they are not the main drivers for $\triangle E L A$. The spatial distribution of $\triangle E L A$ shows a distinct pattern along the west-east and north-south transects, with larger $\triangle$ ELAs occurring in the west and on the northern slopes, but smaller values in the central eastern
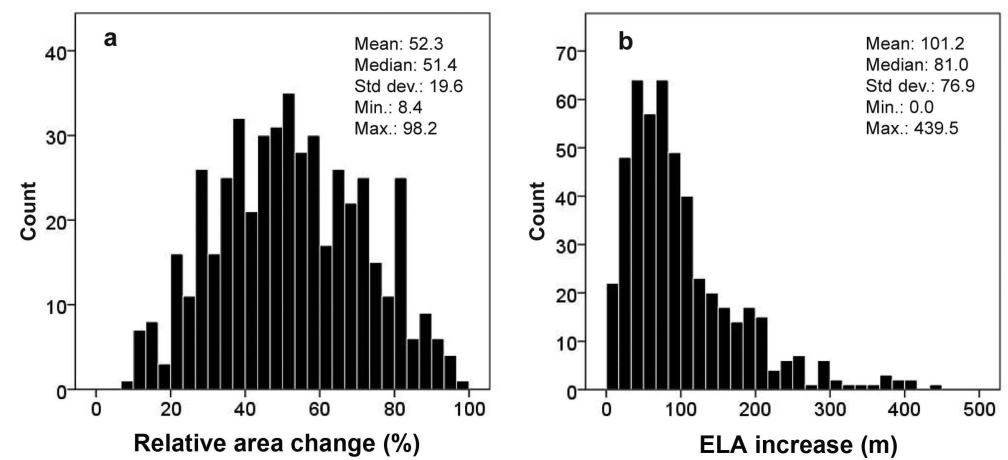

Fig. 4. Frequency distribution of two glacier change indicators: (a) relative area change and (b) $\Delta E L A$. 


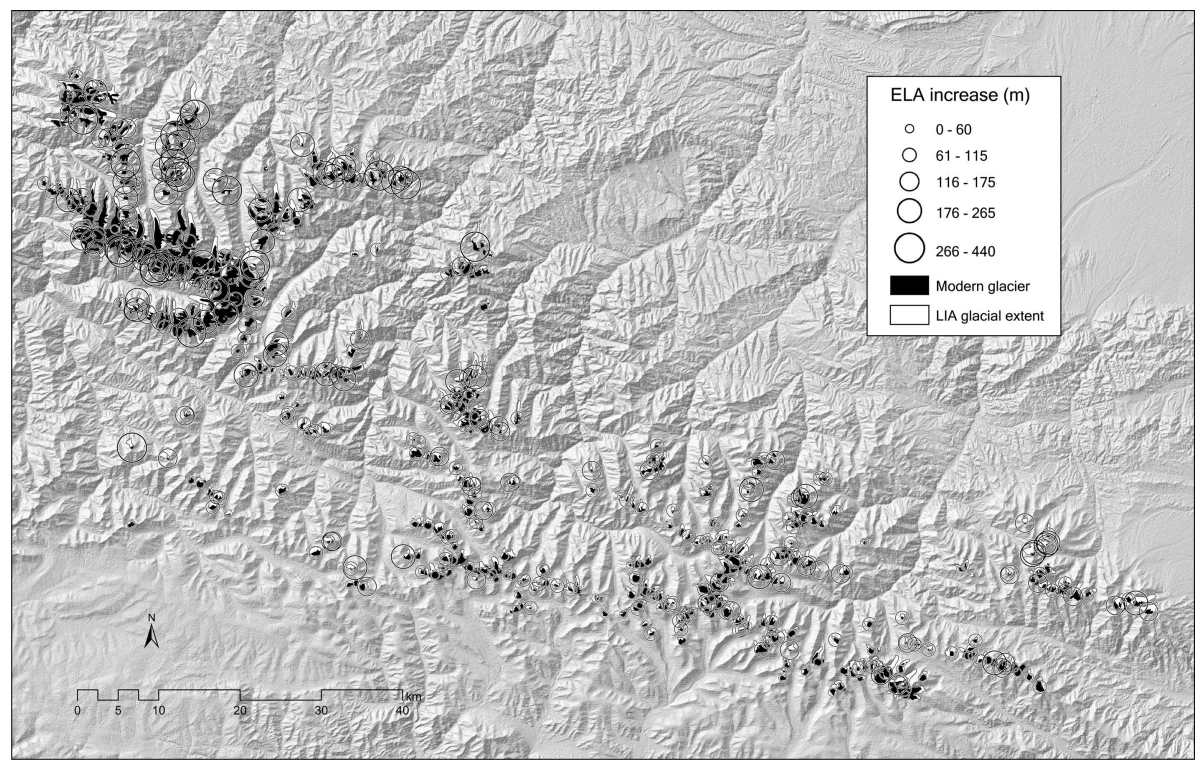

Fig. 5. Spatial distribution of $\Delta \mathrm{ELA}$ in the study area.

areas and on the southern slopes (Fig. 5). Such a pattern is in accordance with the precipitation distribution in the Tien Shan: more precipitation falls in the western and northern ranges and less precipitation on the southern slopes. Although Benn and Lehmkuhl (2000) suggested that local factors such as slope, aspect and hypsometry can contribute to $\triangle E L A$ for clean and snowfall-fed glaciers, our results suggest that only a small portion of the $\triangle E L A$ can be explained by local factors in the central Tien Shan. Climatic factors, such as precipitation and temperature, are more likely causing the spatial differences in $\Delta$ ELAs.

\section{Relationship between relative area change and local factors}

In contrast to $\triangle E L A$, we obtained a strong relationship between relative glacial area change and two of the six local factors:

$$
\Delta A=304.468-11.286 \times \ln A-0.028 \times E
$$

where $\Delta A$ is the relative area change (\%), $\ln A$ is the logarithmic value of the glacier area $\left(\mathrm{m}^{2}\right)$ and $E$ is the mean elevation $(\mathrm{m})$. The $R^{2}$ value is $0.640(p<0.001$; Table 2$)$. The scatter plot illustrates a good fit of the regression (Fig. 6a). Therefore, our results suggest that the relative area change of a glacier is closely associated with its area and mean elevation. Glacier area is commonly believed to be a key

Table 1. Regression between $\triangle \mathrm{ELA}$ and six local factors

\begin{tabular}{lrrr}
\hline Explanatory variable & Parameter estimate & $p$ value & $R^{2}$ \\
\hline Intercept & 262.752 & 0.026 & \\
In(area) & -2.542 & 0.485 & \\
Mean elevation & -0.003 & 0.906 & \\
Cosine of aspect & -60.057 & 0.000 & \\
Slope & 2.263 & 0.000 & \\
Shape index & -87.052 & 0.001 & \\
Hypsometric integral & -64.700 & 0.172 & \\
Whole model & & 0.000 & 0.162
\end{tabular}

factor affecting glacier shrinkage (Khromova and others, 2003; Liu and others, 2003; Bhambri and others, 2011; Li and others, 2011). The scatter plot of In $A$ vs relative area change and its high correlation coefficient $(r=-0.766 ; p<0.001)$ indicate that small glaciers tend to have relatively high area reductions (Fig. 6b). This finding is consistent with studies of recent decadal glacier changes in other regions such as the European Alps (Paul and others, 2004), the northern Kyrgyz Tien Shan (Bolch, 2007), the central Himalaya (Bhambri and others, 2011) and the eastern Chinese Tien Shan (Li and others, 2011). The mean elevation is also well correlated with relative area change $(r=-0.405 ; p<0.001)$ (Fig. $6 \mathrm{c})$, suggesting that glaciers distributed at high elevations tend to recede slowly compared with those at low elevations.

Although other factors did not show significant contributions to glacier change in this area, the correlation analysis suggested that most pairwise correlations are significant at the 0.001 level (Table 3). Glaciers on steeper slopes tend to have large relative area loss. Glacier $\mathrm{SI}$ has a negative correlation with $\triangle E L A$, but a positive correlation with relative area change. This probably indicates that when a glacier is nearly round in shape, it becomes too small to have a large $\triangle \mathrm{ELA}$, but can still lead to relatively large area loss. $\mathrm{HI}$ has a positive correlation with relative area change, but at a relatively low level $(r=0.124 ; p=0.006)$. For the aspect, our results showed a relatively high percentage of relative area reduction for north-facing glaciers (Fig. 6d). Most previous studies have suggested that south-facing glaciers are prone to have larger area loss due to greater

Table 2. Regression between relative glacier area change and two statistically significant local factors

\begin{tabular}{lrrr} 
Explanatory variable & Parameter estimate & $p$ value & $R^{2}$ \\
\hline Intercept & 304.475 & 0.000 & \\
In(area) & -11.286 & 0.000 & \\
Mean elevation & -0.028 & 0.000 & \\
Whole model & & 0.000 & 0.640
\end{tabular}



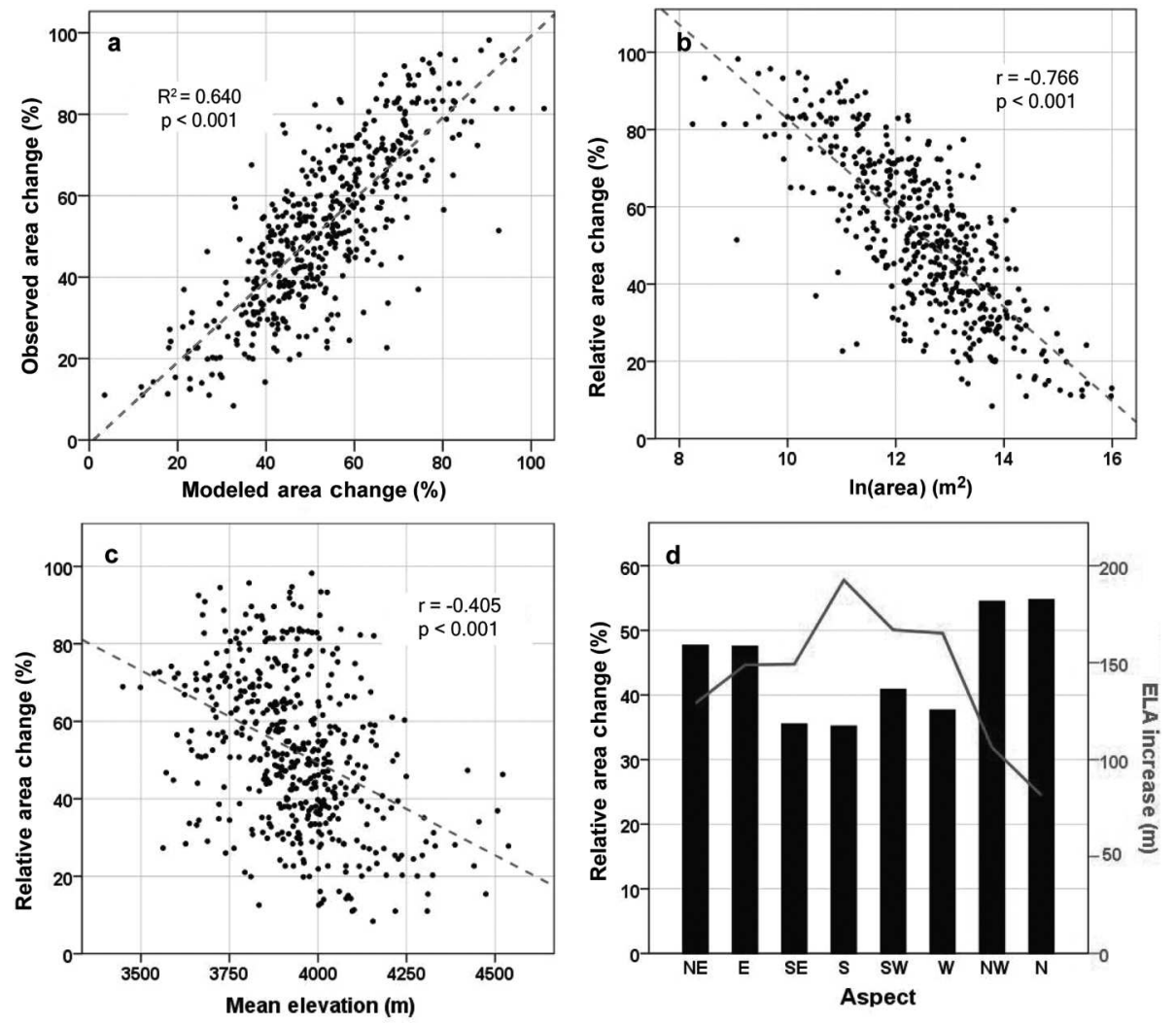

Fig. 6. (a) Scatter plot of the observed relative area change (\%) vs the modeled area change (\%) from Eqn (2). (b, c) Scatter plots of two statistically significant local factors, In(area) and mean elevation vs relative area change, respectively. (d) Relative area change and $\Delta$ ELA in eight different directions of the average aspect for each glacier.

incoming solar radiation (e.g. Evans, 2006; Li and others, 2011). Our inverse result is probably caused by the intrinsic sampling bias in the study, which unbalanced the binomial frequency distribution of south- and north-facing glaciers and resulted in non-randomized sampling. One possible reason for the lack of south-facing glaciers is that most of them have already disappeared and we were unable to identify the empty glacier basins that should have $100 \%$ glacier area loss. Therefore, the value of $42.3 \%$ glacier area reduction since the LIA is most likely underestimated.

\section{Comparison with nearby regions}

Our study showed that, since the LIA maximum, glaciers in the central Tien Shan have lost $\sim 42.3 \%$ of their area, with a mean ELA increase of $\sim 100 \mathrm{~m}$. Savoskul (1997) reported two retreat patterns since the LIA maximum for 20 glaciers in the Kyrgyz Tien Shan ( $740 \mathrm{~km}$ west of our study area) based on $1: 100000$ topographic maps. In the warm and humid western frontal ranges, the relative area loss reached 50-90\% and the ELA increased by 100-200 m (estimated by various methods including the median elevation, THAR, AAR and MELM); whereas, in the inner cold and arid ranges, glaciers were more stable, with $3-7 \%$ area reductions and 20-50 m increases in ELA. Our calculated relative area change and $\triangle E L A$ in the central Tien Shan are similar to the pattern of the warm and humid western frontal ranges, but different from the pattern in the inner cold and arid ranges. This difference highlights the need to examine detailed

Table 3. Pearson correlation coefficients for topographic/geometric factors and glacier change indicators. Bold numbers indicate significance at the 0.001 level $(p<0.001)$

\begin{tabular}{|c|c|c|c|c|c|c|c|c|}
\hline & $\ln ($ area) & Cosine of aspect & Slope & Shape index & $\begin{array}{l}\text { Hypsometric } \\
\text { integral }\end{array}$ & Mean elevation & Area change & $\Delta \mathrm{ELA}$ \\
\hline & $\mathrm{m}^{2}$ & & ० & & & $\mathrm{m}$ & $\%$ & $\mathrm{~m}$ \\
\hline $\ln ($ area $)$ & 1.000 & & & & & & & \\
\hline Cosine of aspect & -0.096 & 1.000 & & & & & & \\
\hline Slope & -0.398 & 0.027 & 1.000 & & & & & \\
\hline Shape index & -0.474 & 0.201 & -0.027 & 1.000 & & & & \\
\hline Hypsometric integral & -0.253 & -0.106 & 0.222 & 0.157 & 1.000 & & & \\
\hline Mean elevation & 0.233 & -0.604 & 0.003 & -0.140 & 0.417 & 1.000 & & \\
\hline Area change & -0.766 & 0.242 & 0.325 & 0.318 & 0.124 & -0.405 & 1.000 & \\
\hline$\Delta \mathrm{ELA}$ & 0.018 & -0.311 & 0.171 & -0.231 & -0.021 & 0.158 & 0.018 & 1.000 \\
\hline
\end{tabular}


glacier changes across different regions to fully understand the climatic and local controls on glacier changes in the Tien Shan. Solomina (2000) and Solomina and others (2004) examined a large dataset of glacier changes in the Kyrgyz Tien Shan and reported an average $\triangle E L A$ of $70 \mathrm{~m}$ from the LIA maximum to the 1980 s using the TSAM, the same method used in our study. This $\triangle$ ELA estimate is similar to the value we derived in the central Tien Shan. Liu and others (2003) conducted a study on glacier change in the western Qilian Shan ( $\sim 1000 \mathrm{~km}$ southeast of our study area) since the LIA maximum, based on aerial photographs from 1956, $1: 50000$ topographic maps from the 1970s, and Landsat Thematic Mapper (TM) images from 1990. They found that, from the LIA to 1990, glacier area decreased by $25-28 \%$, and the ELA of small glaciers increased by $46 \mathrm{~m}$ to the $1950 \mathrm{~s}$ ( $\triangle \mathrm{ELA}$ was estimated using the elevations of glacier termini in different periods; Liu and others, 2003). They also found that the decrease in glacier area between 1956 and 1990 was comparable to the decrease between the LIA and 1956, which indicates a much faster shrinking rate in recent decades. Considering the accelerated retreat rate after 1956 found in their study, glaciers in the western Qilian Shan might have experienced a similar or even larger magnitude of retreat compared with our results in the central Tien Shan. In the Ürümqi river headwaters where Ürümqi glacier No. 1 is located, previous studies reported the presence of 143 glaciers, with a total area of $67.6 \mathrm{~km}^{2}$, during the LIA maximum, but in 1964 only 124 glaciers remained, with a total area of $38.0 \mathrm{~km}^{2}$, indicating an area reduction of $43.8 \%$ and an increase in ELA of 100-130 m (estimated based on the temperature depression derived from the tree-ring record; Shi and Ren, 1990), similar to our results.

Topographic/geometric controls on glacier changes have been examined mainly for recent decades because of the availability of remote-sensing data. Similar to our results in the central Tien Shan, studies on the Bogeda range, eastern Tien Shan (Li and others, 2011), and the Garhwal Himalaya, India (Bhambri and others, 2011), also concluded that small glaciers were more sensitive to climate change. In addition, our results indicate that glaciers tend to recede slowly at high elevations. This relationship is valid in many regions (Aizen and others, 2007; Racoviteanu and others, 2008; Li and others, 2011), but in others an inverse relationship occurs for different glacier types. For example, in the Garhwal Himalaya, larger compound glaciers, which extend to lower valleys, recede at a relatively slower rate, while faster-receding smaller glaciers are found at higher elevations (Bhambri and others, 2011). Previous studies also found the fragmentation and disappearance of glaciers over recent decades (Liu and others, 2003; Bhambri and others, 2011; Li and others, 2011). The fact that only $4 \%$ of glaciers are south-facing in our study area may indicate a similar pattern to that identified in other studies, that south-facing glaciers have more area loss than north-facing glaciers (Nainwal and others, 2008).

\section{Limitations}

Several limitations still exist in our study. First, bias may be introduced by not counting glaciers that have disappeared (mainly south-facing glaciers). During the delineation, we also excluded some glaciers covered by clouds in satellite imagery, potentially causing additional bias in our analysis. Second, the time range of satellite imagery in Google Earth spans 10 years (2002-12). Therefore, the extents delineated for different glaciers may not be from the same year, causing some minor inconsistency. Finally, the LIA moraines were only dated in one valley, and more absolute geological dating of these moraines in other valleys is required in the future.

\section{CONCLUSIONS}

We conducted a detailed study of local topographic/ geometric controls on glacier changes in the central Tien Shan since the LIA maximum, based on 487 glaciers and their corresponding LIA extents delineated from satellite imagery in Google Earth. Six topographic/geometric factors, i.e. glacier area, slope, aspect, shape, hypsometry and mean elevation, were evaluated with two glacier change indicators: relative area change and $\triangle \mathrm{ELA}$ (estimated using the TSAM). Our results show that the total glacier area decreased from $460.2 \mathrm{~km}^{2}$ during the LIA to $265.6 \mathrm{~km}^{2}$ in the $2000 \mathrm{~s}(42.3 \%)$, with an average ELA increase of $~ 100 \mathrm{~m}$. These estimations are comparable with other studies in nearby regions of central Asia. The relationship between $\triangle$ ELA and these local factors is not significant $\left(R^{2}=0.162\right)$, indicating that $\triangle \mathrm{ELA}$ is probably affected mainly by climate rather than local settings. In contrast, relative area changes of these glaciers are strongly correlated with local factors, especially the area and mean elevation of a glacier $\left(R^{2}=0.640\right)$. Specifically, small glaciers tend to have large relative area loss, and glaciers at high elevations tend to recede slowly.

\section{ACKNOWLEDGEMENTS}

This work was supported by the National Science Foundation of China (41328001, 41230523 and 40971002), the National Geographic Society Young Explorers Grant (908612) and the National Science Foundation Doctoral Dissertation Improvement Research Grant (BCS-1303175). We thank Nicholas Nagle for advice on, and improvement of, the statistics, Yang Xu and Jiaoli Chen for help with the GIS analysis, and Rebecca Potter and Lorelei Bryan for discussions on, and improvement of, the writing. We also thank Donghui Shangguan and an anonymous reviewer for valuable comments and suggestions.

\section{REFERENCES}

Aizen VB, Aizen EM and Melack JM (1995) Climate, snow cover, glaciers and runoff in the Tien Shan, central Asia. Water Resour. Bull., 31(6), 1-17 (doi: 10.1111/j.1752-1688.1995.tb03426.x)

Aizen VB, Kuzmichenok VA, Surazakov AB and Aizen EM (2007) Glacier changes in the Tien Shan as determined from topographic and remotely sensed data. Global Planet. Change, 56(3-4), 328-340 (doi: 10.1016/j.gloplacha.2006.07.016)

Asahi K (2010) Equilibrium-line altitudes of the present and Last Glacial Maximum in the eastern Nepal Himalayas and their implications for SW monsoon climate. Quat. Int., 212(1), 26-34 (doi: 10.1016/j.quaint.2008.08.004)

Benn DI and Lehmkuhl F (2000) Mass balance and equilibrium-line altitudes of glaciers in high mountain environments. Quat. Int., 65-66, 15-29 (doi: 10.1016/S1040-6182(99)00034-8)

Bhambri R, Bolch T, Chaujar RK and Kulshreshtha SC (2011) Glacier changes in the Garwal Himalaya, India, from 1968 to 2006 based on remote sensing. J. Glaciol., 57(203), 543-556 (doi: 10.3189/002214311796905604) 
Bliss A, Hock R and Cogley JG (2013) A new inventory of mountain glaciers and ice caps for the Antarctic periphery. Ann. Glaciol., 54(63 Pt 2), 191-199 (doi: 10.3189/2013AoG63A377)

Bolch T (2007) Climate change and glacier retreat in northern Tien Shan (Kazahkstan/Kyrgyzstan) using remote-sensing data. Global Planet. Change, 56(1-2), 1-12 (doi: 10.1016/ j.gloplacha.2006.07.009)

Bolch T and 11 others (2012) The state and fate of Himalayan glaciers. Science, 336(6079), 310-314 (doi: 10.1126/science. 1215828)

Chen J (1989) Preliminary researches on lichenometric chronology of Holocene glacial fluctuations and on other topics in the headwater of Ürümqi river, Tian Shan mountains. Sci. China B, 32(12), 1487-1500 [in Chinese with English summary]

Chen X, Luo G, Xia J, Zhou K, Lou S and Ye M (2005) Ecological response to the climate change on the northern slope of the Tianshan Mountains in Xinjiang. Sci. China D, 48(6), 765-777 (doi: 10.1360/04yd0050)

Cook AJ, Fox AJ, Vaughan DG and Ferrigno JG (2005) Retreating glacier fronts on the Antarctic Peninsula over the past halfcentury. Science, 308(5721), 541-544 (doi: 10.1126/science. 1104235)

Evans IS (2006) Local aspect asymmetry of mountain glaciation: a global survey of consistency of favoured directions for glacier numbers and altitudes. Geomorphology, 73(1-2), 166-184 (doi: 10.1016/j.geomorph.2005.07.009)

Frankl A, Zweertvaegher A, Poesen J and Nyssen J (2013) Transferring Google Earth observations to GIS-software: example from gully erosion study. Int. J. Digital Earth, 6(2), 196-201 (doi 10.1080/17538947.2012.744777)

Gao M, Han T, Ye B and Jiao K (2013) Characteristics of meltwater discharge in the Glacier No. 1 basin, headwater of Ürümqi River. J. Hydrol., 489, 180-188 (doi: 10.1016/j.jhydrol. 2013.03.013)

Grove JM (2004) Little ice ages: ancient and modern, 2nd edn. Routledge, London

Huybers K and Roe GH (2009) Spatial patterns of glaciers in response to spatial patterns in regional climate. J. Climate, 22(17), 4606-4620 (doi: 10.1175/2009JCLI2857.1)

Kamp U, Byrne M and Bolch T (2011) Glacier fluctuations between 1975 and 2008 in the Greater Himalaya Range of Zanskar, southern Ladakh. J. Mt. Sci., 8(3), 374-389 (doi: 10.1007/ s11629-011-2007-9)

Kerr RA (2013) Melting glaciers, not just ice sheets, stoking sealevel rise. Science, 340(6134), 798 (doi: 10.1126/science.340. 6134.798)

Khromova TE, Dyurgerov MB and Barry RG (2003) Late-twentieth century changes in glacier extent in the Ak-shirak Range, Central Asia, determined from historical data and ASTER imagery. Geophys. Res. Lett., 30(16), 1863 (doi: 10.1029/ 2003GL017233)

Li K, Li H, Wang L and Gao W (2011) On the relationship between local topography and small glacier change under climatic warming on Mt Bogda, eastern Tian Shan, China. J. Earth Sci., 22(4), 515-527 (doi: 10.1007/s12583-011-0204-7)

Li Y, Liu G and Cui Z (2001) Glacial valley cross-profile morphology, Tian Shan Mountains, China. Geomorphology, 38(1-2), 153-166 (doi: 10.1016/S0169-555X(00)00078-7)

Li Y, Napieralski J and Harbor J (2008) A revised automated proximity and conformity analysis method to compare predicted and observed spatial boundaries of geologic phenomena. Comput. Geosci., 34(12), 1806-1814 (doi: 10.1016/j.cageo.2008.01.003)

Li Y, Liu G, Kong P, Harbor J, Chen Y and Caffee M (2011) Cosmogenic nuclide constraints on glacial chronology in the source area of the Ürümqi River, Tian Shan, China. J. Quat. Sci., 26(3), 297-304 (doi: 10.1002/jqs.1454)

Liu C and Han T (1992) Relation between recent glacier variations and climate in the Tien Shan Mountains, central Asia. Ann. Glaciol., 16, 11-16
Liu S, Sun W, Shen Yand Li G (2003) Glacier changes since the Little Ice Age maximum in the western Qilian Shan, northwest China, and consequences of glacier runoff for water supply. J. Glaciol., 49(164), 117-124 (doi: 10.3189/172756503781830926)

Maisch M (1992) Die Gletscher Graubündens: Rekonstruktionen und Auswertung der Gletscher und deren Veränderungen seit dem Hochstand von 1850 im Gebiet der östlichen Schweizer Alpen (Bündnerland und angrenzende Regionen). (Physische Geographie 33) Universität Zürich, Zürich

Nainwal HC, Negi BDS, Chaudhary M, Sajwan KS and Gaurav A (2008) Temporal changes in rate of recession: evidence from Satopanth and Bhagirath Kharak glaciers, Uttarakhand, using Total Station Survey. Current Sci., 94(5), 653-660

Narama C, Kääb A, Duishonakunov $M$ and Abdrakhmatov $K$ (2010) Spatial variability of recent glacier area changes in the Tien Shan Mountains, Central Asia, using Corona ( 1970), Landsat ( 2000) and ALOS ( 2007) satellite data. Global Planet. Change, 71(1-2), 42-54 (doi: 10.1016/ j.gloplacha.2009.08.002)

Paul F, Kääb A, Maisch M, Kellenberger T and Haeberli W (2004) Rapid disintegration of Alpine glaciers observed with satellite data. Geophys. Res. Lett., 31(21), L21402 (doi: 10.1029/ 2004GL020816)

Pike RJ and Wilson SE (1971) Elevation-relief ratio, hypsometric integral and geomorphic area-altitude analysis. Geol. Soc. Am. Bull., 82(4), 1079-1084 (doi: 10.1130/0016-7606(1971)82 [1079:ERHIAG]2.0.CO;2)

Porter SC (1970) Quaternary glacial record in Swat Kohistan, west Pakistan. Geol. Soc. Am. Bull., 81(5), 1421-1446 (doi: 10.1130/ 0016-7606(1970)81[1421:QGRISK]2.0.CO;2)

Racoviteanu AE, Arnaud Y, Williams MW and Ordoñez J (2008) Decadal changes in glacier parameters in the Cordillera Blanca, Peru, derived from remote sensing. J. Glaciol., 54(186), 499-510

Savoskul OS (1997) Modern and Little Ice Age glaciers in 'humid' and ' $\mathrm{arid}^{\prime}$ ' areas of the Tien Shan, central Asia: two different patterns of fluctuation. Ann. Glaciol., 24, 142-147

Shi Y and Ren J (1990) Glacier recession and lake shrinkage indicating a climatic warming and drying trend in central Asia. Ann. Glaciol., 14, 261-265

Solomina ON (2000) Retreat of mountain glaciers of northern Eurasia since the Little Ice Age maximum. Ann. Glaciol., 31, 26-30 (doi: 10.3189/172756400781820499)

Solomina O, Barry R and Bodnya M (2004) The retreat of Tien Shan glaciers (Kyrgyzstan) since the Little Ice Age. Geogr. Ann. A, 86(2), 205-215 (doi: 10.1111/j.0435-3676.2004.00225.x)

Sorg A, Bolch T, Stoffel M, Solomina O and Beniston M (2012) Climate change impacts on glaciers and runoff in Tien Shan (Central Asia). Nature Climate Change, 2(10), 725-731 (doi: 10.1038/nclimate1592)

Sun X, Shen S, Leptoukh GG, Wang P, Di L and Lu M (2012) Development of a Web-based visualization platform for climate research using Google Earth. Comput. Geosci., 47 160-168 (doi: 10.1016/j.cageo.2011.09.010)

Torsnes I, Rye N and Nesje A (1993) Modern and Little Ice Age equilibrium-line altitudes on outlet valley glaciers from Jostedalsbreen, western Norway: an evaluation of different approaches to their calculation. Arct. Alp. Res., 25(2), 106-116

Wang Z (2010) The changes of Lop Nur Lake and the disappearance of Loulan. J. Arid Land, 2(4), 295-303 (doi: 10.3724/ SP.J.1227.2010.00295)

Xu X, Kleidon A, Miller L, Wang S, Wang L and Dong G (2010) Late Quaternary glaciation in the Tianshan and implications for palaeoclimatic change: a review. Boreas, 39(2), 215-232 (doi: 10.1111/j.1502-3885.2009.00118.x)

Yang B, Bräuning A, Dong Z, Zhang Z and Jiao K (2008) Late Holocene monsoonal temperate glacier fluctuations on the Tibetan Plateau. Global Planet. Change, 60(1-2), 126-140 (doi: 10.1016/j.gloplacha.2006.07.035) 
Ye B and 6 others (2005) The Ürümqi River source Glacier No. 1, Tianshan, China: changes over the past 45 years. Geophys. Res. Lett., 32(21), L21504 (doi: 10.1029/2005GL024178)

Yi C, Liu K, Cui Z, Jiao K, Yao T and He Y (2004) AMS radiocarbon dating of late Quaternary glacial landforms, source of the Ürümqi River, Tien Shan - a pilot study of ${ }^{14} \mathrm{C}$ dating on inorganic carbon. Quat. Int., 121(1), 99-107 (doi: 10.1016/ j.quaint.2004.01.026)
Yi C and 6 others (2008) Review of Holocene glacial chronologies based on radiocarbon dating in Tibet and its surrounding mountains. J. Quat. Sci., 23(6-7), 533-543 (doi: 10.1002/ jqs.1228)

Yu L and Gong P (2012) Google Earth as a virtual globe tool for Earth science applications at the global scale: progress and perspectives. Int. J. Remote Sens., 33(12), 3966-3986 (doi: $0.1080 / 01431161.2011 .636081$ 